\title{
STRATEGI BISNIS DALAM MENINGKATKAN DAYA SAING PADA CV BANGUN JAYA DI BANDAR LAMPUNG
}

\author{
M. Yusuf Sulfarano Barusman \\ Fakultas Ekonomi, Universitas Bandar \\ Lampung \\ Email : yusuf.barusman@ubl.ac.id \\ Cindy Ramlee \\ Fakultas Ekonomi, Universitas Bandar Lampung \\ Email : cindyramlee1544@gmail.com
}

\begin{abstract}
ABSTRAK
Penelitian ini bertujuan untuk mengidentifikasi keunggulan bersaing CV Bangun Jaya berdasarkan faktor pengukur daya saing, serta menghasilkan alternatif strategi dalam rangka mengeskploitasi keunggulan bersaing tersebut untuk menciptakan keunggulan bersaing berkelanjutan bagi perusahaan. Metode penelitian yang digunakan adalah kualitatif. Hasil penelitian diperoleh bahwa perusahaan memiliki keunggulan bersaing. Kemudian keunggulan bersaing tersebut dianalisis menggunakan kerangka VRIO dan memberikan hasil bahwa perusahaan hanya memenuhi tiga kriteria VRIO yaitu, berharga (valuable),jarang (rare), dan tidak mudah ditiru (inimitable). Sehingga menghasilkan keunggulan bersaing yang belum bisa digunakan. Perusahaan dapat mencapai keunggulan bersaing yang berkelanjutan dengan melakukan alternatif strategi. Alternatif strategi yang dapat dilakukan oleh CV Bangun Jaya adalah meningkatkan teknologi yang digunakan dan mengoptimalkan bidang pemasarannya. Kata Kunci: faktor daya saing, keunggulan bersaing, kerangka VRIO, alternatif strategi.
\end{abstract}

ABSTRACT

The aims of this study are identifies the competitive advantage of CV Bangun Jaya based on compeitiveness measuring factors and produces the alternative strategies in order to exploit the competitive advantage to create sustainable competitive advantage for the company. This research is using qualitative methode. The result shows that the company has a competitive advantage. The analysis uses the VRIO framework and it gives the results that the company only has three criterias of VRIO, valuable, rare and inimitable, which means the competitive advantage of CV Bangun Jaya is Unused Competitive Advantage, not sustainable competitive advantage. The company can achieve a sustainable competitive advantage by creating the formulation strategy. The alternative strategies that the company could apply are upgrade the technology and optimize the marketing sector.

Keywords : competitiveness measuring factors, competitive advantage, VRIO framework, alternative strategy.

\section{PENDAHULUAN}

\section{Latar Belakang Masalah}

Industri jasa konstruksi merupakan salah satu hal penting dalam pembangunan suatu negara karena industri jasa konstruksi adalah usaha yang menghasilkan produk berupa prasarana dan sarana fisik yang merupakan landasan pertumbuhan sektor-sektor dalam pembangunan nasional. Menurut UU No. 2 Tahun 2017 tentang jasa konstruksi, jasa konstruksi ialah layanan jasa konsultansi 
perencanaan pekerjaan konstruksi, layanan jasa pelaksanaan pekerjaan konstruksi dan layanan jasa konsultansi pengawasan pekerjaan konstruksi. Pekerjaan Konstruksi adalah keseluruhan atau sebagian rangkaian kegiatan perencanaan dan/atau pelaksanaan beserta pengawasan yang mencakup pekerjaan arsitektural, sipil, mekanikal, elektrikal dan tata lingkungan masing-masing beserta kelengkapannya untuk mewujudkan suatu bangunan atau bentuk fisik lain. Sekarang ini bisnis jasa konstruksi mengalami persaingan yang semakin ketat seiring berjalannya waktu. Persaingan ini ditandai dengan meningkatnya jumlah perusahaan jasa konstruksi yang ada. Menurut Direktur Jenderal Bina Konstruksi Kementerian Pekerjaan Umum dan Perumahan Rakyat (PUPR) Yusid Toyib, Industri jasa konstruksi mengalami pertumbuhan signifikan sekitar 30\% selama tiga tahun terakhir (2014 2016). Di Lampung pun telah banyak didirikan perusahaan yang bergerak di bidang jasa konstruksi, salah satunya adalah CV Bangun Jaya. Ssaat ini, CV Bangun Jaya tengah merasakan tantangan dalam menjalankan usahanya.

Berdasarkan data jumlah perusahaan konstruksi di Lampung tahun 2013-2016 didapatkan dapat diketahui bahwa setiap tahun terjadi peningkatan jumlah perusahaan konstruksi. Dan dari data jumlah pendapatan CV Bangun Jaya tahun 2013-2016 diketahui bahwa jumlah pendapatan CV Bangun Jaya mengalami penurunan rata-rata sebesar 14,3 persen. Maka dari itu, karena CV Bangun Jaya masih mengalami rata-rata penurunan jumlah kosumen dan pendapatan, CV Bangun Jaya harus lebih meneliti lagi kualifikasi perusahaan untuk meningkatkan daya saing. Menurut Barney, J.B. (1991) dalam karyanya "Firm Resources and Sustained Competitive Advantage", agar sebuah perusahaan mampu menghadapi persaingan dan tetap berkembang, perusahaan tersebut harus mempertahankan keunggulan bersaing secara berkelanjutan.(Sustainable Competitive Advantage). Oleh karena itu, upaya membangun keunggulan bersaing berkelanjutan bagi $\mathrm{CV}$ Bangun Jaya sangatlah penting dan sudah selayaknya menjadi perhatian perusahaan.

\section{Permasalahan}

Dari latar belakang didapatkan bahwa permasalahn yang terdapat pada CV Bangun Jaya adalah

1. Menurunnya jumlah pendapatan CV Bangun Jaya tahun 2013-2016 dengan penurunan rata-rata sebesar 14,3 persen yang dapat dilihat pada tabel 1.3.

2. CV Bangun Jaya membutuhkan strategi bisnis dalam upaya meningkatkan daya saing perusahaan.

\section{Tujuan Penelitian}

Tujuan yang hendak dicapai dalam rangka penelitian ini yaitu untuk mengetahui Strategi Bisnis apa yang dapat dilakukan dalam meningkatkan daya saing pada CV Bangun Jaya di Bandar Lampung.

\section{TINJAUAN PUSTAKA}

\section{Manajemen}

Menurut George R. (2011:3) Manajemen adalah pencapaian tujuan-tujuan yang telah ditetapkan melalui atau bersama-sama usaha orang lain. Manajemen sangat penting bagi setiap aktivitas individu atau kelompok dalam organisasi untuk mencapai tujuan yang diinginkan. Manajemen berorientasi pada proses (process oriented) yang berarti bahwa manajemen membutuhkan sumber daya manusia, pengetahuan, dan keterampilan agar aktivitas menjadi lebih efektif atau dapat menghasilkan tindakan dalam mencapai kesuksesan. Oleh sebab itu, tidak akan ada organisasi yang akan sukses apabila tidak menggunakan manajemen yang baik.

\section{Strategi}

Menurut Husein Umar (2010:20) yang menyatakan bahwa strategi merupakan tindakan yang bersifat incremental (senantiasa meningkat) dan terus menerus, serta dilakukan berdasarkan sudut pandang tentang apa yang diharapkan oleh para pelanggan di masa depan. Dengan demikian, strategi selalu dimulai dari apa yang dapat terjadi dan bukan dimulai dari apa yang terjadi. Terjadinya kecepatan inovasi pasar yang baru dan perubahan pola konsumen memerlukan kompetensi inti (core 
competencies).Perusahaan perlu mencari kompetensi inti didalam bisnis yang dilakukan.

\section{Manajemen Strategi}

Menurut Fred R. David (2012) menjelaskan bahwa manajemen strategis terdiri dari tiga tahapan, yaitu, memformulasikan strategi, mengimplementasikan strategi dan mengevaluasi strategi.

Tahap memformulasikan strategi antara lain menetapkan visi dan misi, mengidentifikasi peluang dan tantangan yang dihadapi organisasi dari sudut pandang eksternal, menetapkan kelemahan dan keunggulan yang dimiliki organisasi dari sudut pandang internal.

Tahap mengimplementasikan strategi memerlukan suatu keputusan dari pihak yang berwenang dalam mengambil keputusan untuk menetapkan tujuan tahunan, membuat kebijakan, memotivasi pegawai, dan mengalokasikan sumber daya yang dimiliki sehingga strategi yang sudah diformulasikan dapat dilaksanakan.

Tahap mengevaluasi strategi adalah tahap terakhir dalam manajemen strategis. Para manajer sangat perlu untuk mengetahui ketika ada strategi yang sudah diformulasikan tidak berjalan dengan baik. Evaluasi strategi memiliki tiga aktifitas yang fundamental, yaitu mereview faktor-faktor internal dan eksternal yang menjadi dasar untuk strategi saat ini, mengukur performa dan mengambil langkah korektif.

\section{Bisnis}

Menurut Jeff Madura (2010) Bisnis adalah suatu badan yang diciptakan untuk menghasilkan produk barang dan jasa kepada pelanggan. Setiap bisnis mengadakan transaksi dengan orang-orang. Orang-orang itu menanggung akibat karena bisnis tersebut, mereka. Kerjasama lintas fungsional di dalam bisnis adalah dengan menekankan kebutuhan para manajer dari area fungsional yang berbeda untuk memaksimalkan laba dalam mencapai tujuan bersama.

\section{Strategi Bisnis}

Joewono (2012: 3) mengatakan bahwa strategi bisnis adalah strategi mencapai tujuan yang sering dianalogikan dengan strategi catur, yang dimana sistematika berfikir, penyusunan rencana, kesigapan melangkah, keberanian mengambil resiko dan gairah untuk memenangkan pertandingan merupakan beberapa karakteristik permainan catur yang relevan dengan praktek pengelolaan bisnis

\section{Daya Saing}

Kompetisi persaingan adalah inti yang menentukan kesuksesan dan kegagalan perusahaan. Salah satu model bentuk analisa kompetitif yang paling dikenal ialah model kompetitif Porter. Model ini telah digunakan dalam mengembangkan strategi untuk perusahaan dalam meningkatkan kemampuan kompetitif dari perusahaan (Fred. R. David, 2012)

\section{Faktor-faktor Pengukur Daya Saing}

Dibagi menjadi dua, faktor utama dan pendukung. Faktor utama terdiri dari Lokasi, Pelayanan, Harga, Sumber Daya Manusia, serta Mutu dan Kualitas. Sedangkan faktor pendukung, yaitu Supplier, Waktu dan Prosedur Kerja, Standar Kualifikasi, Teknologi, serta Pemasaran. (Ackory;2016) .

\section{Analisis VRIO}

Analisis VRIO dikembangkan oleh Barney, J. B. (1991) dalam karyanya "Firm Resources and Sustained Competitive Advantage,', dan berdasar pada pendekatan Resource Based View , yaitu sebuah acuan untuk meneliti perusahaan dengan memepelajari sumber daya internal perusahaan. Barney, J.B mengidentifikasi sumber daya internal perusahaan harus memiliki 4 atribut VRIO agar dapat digunakan sebagai sumber strategi bisnis dalam meningkatkan daya saing. Menurutnya, sumber daya harus berharga (Valuable), langka (Rare), tidak dapat ditiru (Inimitable) dan perusahaan dikelola dengan baik (Organized).

\section{METODE PENELITIAN}

\section{Jenis dan Sumber Data}




\section{Data Primer}

Data primer adalah data yang diperoleh langsung dari sumber pertama. Sumber pertama dalam penelitian ini adalah pemilik CV Bangun Jaya. Adapun data primer dalam penelitian ini yaitu: data tentang produk yang digunakan, data perkembangan jumlah konsumen, data perkembangan jumlah penjualan dan data-data lain yang berhubungan dengan CV Bangun Jaya.

\section{Data Sekunder}

Data sekunder adalah sumber data penelitian yang diperoleh melalui media perantara atau secara tidak langsung dari bahan bacaan, sumber pustaka, atau perantara lainnya yang sudah tersedia. Adapun data sekunder dari penelitian ini yaitu: data-data yang berasal dari bahan bacaan, literatur dan data yang berasal dari internet.

\section{Teknik Pengumpulan Data}

Dalam penelitian ini peneliti menggunakan teknik pengumpulan data sebagai berikut:

\section{Observasi \\ Pengumpulan data dengan melakukan pengamatan secara langsung ke $\mathrm{CV}$ Bangun Jaya}

\section{Interview}

Teknik pengumpulan data yang dilakukan dengan cara mengajukan pertanyaanpertanyaan yang berkaitan dengan strategi bisnis dan sumber daya CV Bangun Jaya kepada pemilik CV Bangun Jaya.

\section{Dokumentasi}

Teknik pengumpulan data yang dilakukan dengan menggunakan dokumen tertulis (hasil penelitian, laporan tertulis, buku literatur,majalah,jurnal,dan sebagainya) sebagai sumber data penelitian dengan cara melakukan pengelompokan atau klasifikasi data yang berhubungan dengan masalah penelitian.

\section{Metode Analisis}

Metode kerja Analisis VRIO guna menentukan sumber daya dengan keunggulan bersaing berkelanjutan adalah sebagai berikut :

a. Mengidentifikasi sumber daya dengan keunggulan bersaing berdasarkan faktor yang pengukur daya saing.

b. Menganalisis sumber daya dengan keunggulan bersaing CV Bangun Jaya menggunakan kerangka VRIO.

i. Valuable: Apakah sumber daya tersebut dapat digunakan perusahaan untuk mengurangi biaya atau meningkatkan pendapatan?

ii. Rare: Apakah sumber daya tersebut tidak secara bebas dimiliki atau jarang dimiliki oleh perusahaan lain?

iii. Inimitable : Apakah sumber daya tersebut sulit ditiru atau direplikasi perusahaan lain?

iv. Organized : Apakah perusahaan teroganisir dengan baik agar dapat menunjang eksploitasi sumber daya?

c. Diperoleh hasil apakah sumber daya dengan keunggulan bersaing tersebut telah memenuhi indikator VRIO yang kemudian dapat disusun strategi bisnis bagi CV Bangun Jaya.

\section{HASIL DAN PEMBAHASAN}

Berdasarkan hasil wawancara kepada Bapak Edwin Tjahja, pemilik CV Bangun Jaya, Bapak Edwin Tjahja, Bapak Eka, pemilik CV Eka Jaya, Ibu Fitri, sekertaris Bapak Edwin, dan Ibu Wulan, sekertaris Bapak Eka serta konsumen CV Bangun Jaya dan CV Eka Jaya, Ibu Lisa dan Bapak Weli, didapatkan hasil bahwa keunggulan bersaing yang dimiliki CV Bangun Jaya adalah proses pengerjaan proyek yang cepat dengan hasil baik yang memuaskan konsumen.

Setelah didapatkan keunggulan bersaing CV Bangun Jaya, keunggulan bersaing tersebut akan dianalisis lagi menggunakan analisis VRIO untuk menentukan apakah keunggulan bersaing tersebut memenuhi kriteria keunggulan bersaing berkelanjutan. 
Berdasarkan hasil analisis VRIO, didapatkan hasil bahwa CV Bangun Jaya memiliki keunggulan bersaing yang belum terpakai (Unused Competitive Advantage) karena hanya memenuhi kriteria valuable, rare dan inimitable. Sedangkan kriteria organized tidak.

Keunggulan bersaing CV Bangun Jaya telah memiliki kriteria valuable, rare dan inimitable, namun tidak dengan organized. Oleh karena itu diperlukan alternatif strategi agar kriteria organized tersebut terpenuhi sehingga keunggulan bersaing yang dimiliki CV Bangun Jaya bisa menjadi keunggulan bersaing berkelanjutan.

Banyak komponen dalam oganisasi yang berpengaruh terhadap jalannya organisasi, salah satunya teknolgi yang dapat membantu pekerjaan agar lebih efisien dan efektif, struktur laporan, management control system (MCS), dan kebijakan kompensasi. Komponen - komponen ini disebut sumber daya dan komplementer karena tidak dapat menciptakan keunggulan kompetitif akan tetapi dapat mendukung sumber daya atau kapabilitas yang memiliki keunggulan kompetitif sehingga perusahaan dapat merealisasikan seluruh potensi keunggulan kompetitif yang dimiliki.

CV Bangun Jaya telah memiliki laporan struktur namun belum memiliki teknologi khusus yang dapat dijadikan keunggulan perusahaan, serta belum terstrukturnya bidang pemasaran. Sehingga berikut strategi yang dapat penulis rumuskan agar $\mathrm{CV}$ Bangun Jaya memiliki keempat kriteria VRIO.

1. Teknologi

$\checkmark$ Memonitor ketersediaan peralatan dan mesin terbaru yang lebih canggih untuk memberikan hasil yang lebih baik.

$\checkmark$ Melakukan inventarisasi peralatan dan mesin produksi yang dimiliki untuk dilakukan perbaikan atau penggantian.

2. Bidang Pemasaran

$\checkmark$ Memanfaatkan media internet sebagai promosi perusahaan.

$\checkmark$ Merekrut tenaga technical service sebagai media promosi.
Menginformasikan tidak hanya pembangunan rumah namun juga renovasi rumah maupun bangunan lain bagi pelanggan sebagai media promosi perusahaan.

3. Mengoptimalkan keunggulan bersaing $\mathrm{CV}$ Bangun Jaya.

$\checkmark$ Mempertahankan manajemen konstruksi, strategi dan kinerja yang telah diterapkan CV Bangun Jaya.

4. Mengatasi hambatan yang dihadapi CV Bangun Jaya diluar dari faktor utama pengukur daya saing.

$\checkmark$ Mempertimbangkan untuk menambah alternatif strategi selain sistem lembur agar jam kerja tenaga kerja normal yaitu 8 $\mathrm{jam} /$ hari, seperti penambahan jumlah tenaga kerja (buruh) dan dengan sistem shift.

$\checkmark$ Memastikan supplier agar tepat waktu mengirimkan bahan baku. Dan bila memungkinkan, menambah daftar supplier cadangan agar tidak menghambat proses pembangunan apabila bahan baku yang dikirim oleh supplier utama telat.

\section{KESIMPULAN DAN SARAN}

\section{Kesimpulan}

Berdasarkan analisis dan pembahasan pada penelitian ini, maka dapat diambil kesimpulan sebagai berikut :

$\checkmark$ Berdasarkan identifikasi pada CV Bangun Jaya diperoleh hasil bahwa untuk membangun strategi bisnis $\mathrm{CV}$ Bangun Jaya menggunakan kerangka VRIO diperlukan pembaruan dan peningkatan teknologi, serta penstrukturan bidang pemasaran.

$\checkmark$ Sumber Daya CV Bangun Jaya telah dianalisis diperoleh hasil bahwa hanya memenuhi 3 kriteria VRIO yaitu valuable, rare dan inimitable, sedangkan organized tidak.

\section{Saran}

Berdasarkan pembahasan yang ada serta kesimpulan, maka beberapa saran yang dapat dikemukakan adalah sebagai berikut : 
Penelitian ini terfokus pada perumusan strategi berdasarkan keunggulan bersaing yang dimiliki CV Bangun Jaya saat ini.

$\checkmark$ VRIO. Yang perlu dilakukan agar keunggulan bersaing tersebut memnuhi 4 kriteria VRIO adalah memperbarui dan meningkatkan teknologi yang digunakan serta membuat struktur pada bidang pemasaran.

\section{DAFTAR PUSTAKA}

Abdul dan Aulia. (2016). Penelitian Kepustakaan dan Penelitian Lapangan. Jakarta : Universitas Negeri Jakarta.

Ackory. (2016). Analisis Daya Saing Industri Pariwisata Di Kabupaten Samosir. Medan : Universitas Sumatera Utara.

Barney. (1991). Firm Resources and Sustained Competitive Advantage. Texas : A\&M University.

Fred. R. David. (2012). Strategic Management : Manajemen Strategi Konsep, Edisi 12. Jakarta: Salemba Empat.

Jatmiko. (2004). Manajemen Strategik. Edisi pertama, cetakan kedua. Malang: UMM Press.

Joewono, Handito. (2012). The 5 Arrows of Strategic Management. Jakarta: Arrbey.

Madura. (2010). Introduction to Bussiness : Pengantar Bisnis Edisi 4. Jakarta : Salemba Empat.
Keunggulan bersaing yang dimiliki CV Bangun Jaya belum memenuhi 4 kriteria

Moloeng, Lexy J. ( 2005). Metodologi Penelitian Kualitatif, Edisi Revisi. Jakarta : Rosda.

Purbo, Riza Widiasto, Aji Dermawan, Gendut Suprayitno. (2014). Analisis Perumusan Strategi Keunggulan Bersaing Kompetitif Bisnis Pakan Ternak Melalui Pendekatan Resources Based View (Studi Kasus PT Mabar Feed), 12 (3). Bogor : Program Pascasarjana Manajemen dan Bisnis, Institut Pertanian Bogor.

Rangkuti, Freddy. (2013). Strategi Promosi yang Kreatif dan Analisis Kasus Integrated Marketing Communication. Jakarta : Gramedia Pustaka Utama.

Terry, George R. (2011). Prinsip-prinsip Manajemen. Aceh : Bumi Aksara.

Tim O'Shannassy Faculty of Business. (2008). Sustainabe Competitive Advantage or Temporary Competitive Advantage Improving Understanding of An Important Strategy Contruct. Melbourne : Graduate School of RMIT University.

Umar, Husein. (2010). Desain Penelitian Manajemen Strategik No. 3. Jakarta : Rajagrafindo Persada.

Wandrial, Son. (2011). Analisis Internal Perusahaan (Strength \& Weakness) Menggunakan Konsep "Resources Based View of The Firm" Dengan Kerangka VRIO , 2 (2), 627-637. Jakarta : Binus University. 